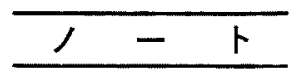

. [農化 第 41 巻，第 2 号, p. $77 \sim 78,1967$ ]

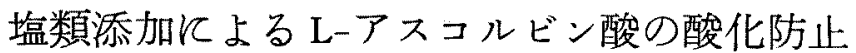

\author{
松下雪郎，岩見舒子，新田ゆき* \\ (京都大学食糧科学研究所, *海星女子学院短期大学)
}

昭和 41 年 9 月 8 日受理

\section{Antioxidative Effects of Salts on the Oxidation of L-Ascorbic Acid \\ (Note)}

By Setsuro Matsushita, Nobuko Iwami and Yuki NitTa*

Research Institute for Food Science, Kyoto University, Kyoto ;

*Kaisei Women's College, Kobe

\begin{abstract}
Antioxidative effects of salts on the oxidation of $\mathrm{L}$-ascorbic acid were tested. All salts which were effective contained halogen or rhodan ions. No relation can be observed between antioxidative effects and cations. Effective anions, halogen and rhodan ions, are situated at the end of the Hofmeister's series which are considerd to show electron-donor properties according to Szent-Györgyi. When ascorbic acid is oxidized, monodehydroascorbic acid having a free radical is formed by one-electron release. Chain oxidation reactions occur by the radicals. Electrons should be added to the radicals in order to protect the chain oxidation reactions. Therefore, it is deduced that the antioxidative effects which were shown by halogen and rhodan ions may be caused by the electron-donor properties of the ions.

(Received September 8, 1966)
\end{abstract}

Lーアスコルビン酸は, 空気中の酸素によって脱水素さ れる。そのさい2 原子の水素が失なかれ，デヒドロアス コルビン酸と過酸化水菜とが生ずる、デヒドロアスコル ビン酸はさらに加水分解をらけて，2，3-L-ジケトグロン 酸定経て低分子物質へと分解される(1)。式第 1 段階デ ヒドロアスコルビン酸の生成は，可逆的であり，第 2 段 階ジケトグロン酸の生成は，不可逆的である(2)。なお，

酸化の過程には，1電子移動によってラジカルであるモ ノデヒドロアスコルビン酸が生成する ${ }^{(3,4)}$. このラジカ ルは，第 1 段階の反応で生じた過酸化水素とともに，連 鎖反広の要因となる，それで，アスコルビン酸の酸化を 防止するには，生じたラジカルに電子を与え，酸化の連 鎖反応を止めなければならない。

アスコルビン酸の酸化防止については，すでに数多く の報告 ${ }^{(5 \sim 14)}$ があり，リン酸塭，食塩，アミノ酸，糖類， 酸類，チ才尿素，グリセリンなどの他，デンプンゼラ
チン,アラビヤゴム，ペクチンなどのコロイド物質が抗 酸化剂として知られている，われわれもまた，塩類の示

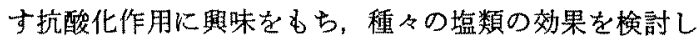
た。.

実験結果は第 1 表に示されるごとくで，抗酸化的に働 いた程類はロダンかカリウムと塩素, 臭素, ヨウ素など のハロダンを゙含む塩類である、すなわち，有効なむのは 陰イオンであったこれらのイオンは，Hofmeister 系 列, citrate $>$ tartrate $>\mathrm{SO}_{4}>$ acetate $>\mathrm{ClO}_{3}>\mathrm{NO}_{3}>\mathrm{Br}$ >I >SCN Kおいては右のほうに位置する、この系列は コロイド活性の順序に従って並べられた，いわゆる lyotropic series であるが, Szent-Györgyi(15) による と、この系列はまた,イオンのるつ電子供与性の順序を 示するのである. (SCN) - 特よび I"は系列の端のほ5 に位置しているから，相対的にすぐれた電子供与体とい

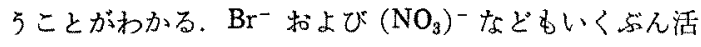


